\title{
DERAJAT INFESTASI Trichodina sp. PADA LELE DUMBO (Clarias gariepinus) DI EMPAT KOLAM PEMBUDIDAYAAN DI KABUPATEN SUMENEP
}

\author{
Miarsono sigit ${ }^{1}$, Adhitya Yoppy Ro Candra ${ }^{1}$, Achmad Rachman Hidayat ${ }^{1}$, Rochiman Sasmita ${ }^{{ }^{*}}$ \\ ${ }^{1}$ Fakultas Kedokteran Hewan, Universitas Wijaya Kusuma Surabaya. \\ *Email : rochiman240444@gmail.com
}

\begin{abstract}
This research was aimed to find out the prevalence and degree of infection Trichodiniasis on the Dumbo catfish (Clarias gariepinus) in four ponds cultivation of Sumenep Regency, East Java. The total of 200 samples of Dumbo catfish were from four cultivation ponds to be examined in the Parasitology laboratory of the Faculty of Veterinary Medicine, Univercity Wijaya Kusuma Surabaya. The examination was carried out by means of scraping mucus as well as taking the gill Lamella and observed under the microscope with 100x and 400x magnification. The results showed that the highest level of Trichodiniasis prevalence was in the cultivation pool $C(64 \%)$ With the degree of infection 5.62 individual parasites/fishes including the category of severe infections while in the pond cultivation A (28\%) With the degree of infection 1.86 individual parasitic/fish, cultivation pool B (30\%) With the degree of infection 2.46 individual parasites/fishes and the cultivation pond D (48\%) With an infection degree 3.02 individual parasites/fishes including a category of mild infections. So using Uji-T can be known results of cases of Trichodiniasis that attacked Dumbo catfish (clarias gariepinus) on four pools of cultivation in Sumenep Regency, East Java showed a very noticeable difference.
\end{abstract}

Keywords: Trichodiniasis, dumbo catfish (clarias gariepinus), prevalence, degree of infection

\section{PENDAHULUAN}

Negara Indonesia yang mempunyai wilayah perairan yang sangat besar di dunia, memiliki salah satu sumber daya alam perairan tawar berupa sungai dan danau yang mencakup sumber mata pencaharian bagi masyarakat atau penduduk di sekitarnya dengan melakukan budidaya ikan. Sistem budidaya yang sekarang diterapkan adalah salah satunya yaitu pembudidayaan kolam (Anshary, 2016).

Komposisi gizi ikan lele dumbo (Clarias gariepinus) meliputi kandungan protein (17,7\%), lemak (4,8\%), mineral (1,2\%), dan air (76 \%) (Ubadilla.A, 2010). Keunggulan ikan lele dumbo (Clarias gariepinus) dibandingkan dengan produk hewani lainnya adalah kaya akan leusin dan lisin. Leusin merupakan asam amino esensial yang sangat diperlukan untuk pertumbuhan anak - anak dan menjaga keseimbangan nitrogen, leusin juga berguna untuk pembentukan protein otot.

Lisin merupakan salah satu dari sembilan asam amino esensial yang sangat dibutuhkan untuk pertumbuhan dan perbaikan jaringan. Lisin juga termasuk asam amino yang begitu sangat penting dan dibutuhkan sekali dalam pertumbuhan dan perkembangan anak - anak (Zaki, 2009).

Trichodina sp. adalah ektoparasit yang sering menginfeksi kulit dan insang, kebiasaan ektoparasit ini menginfeksi semua jenis ikan air tawar. (Sugianti, 2005 oleh Rahmi, 2012). Berbagai penelitian membuktikan bahwasanya ektoparasit Trichodina $s p$. ini memiliki peranan terhadap menurunanya daya pertahanan tubuh ikan dan selalu terjadinya infeksi sekunder.

Populasi Trichodina sp. dalam air meningkat pada saat bergantinya musim, yaitu dari musim kemarau ke musim penghujan. Berkembang biaknya dengan cara membelahan diri berlangsung di tubuh ikan lele dan Trichodina $s p$. sangat mudah berenang secara bebas, dapat melepaskan diri dari tubuh ikan lele dan Trichodina $s p$. mampu juga hidup lebih dari 2 hari tanpa adanya host definitif. Ektoparasit Trichodina $s p$. jenis ini mepunyai juga 2 bagian yaitu adalah anterior dan posterior yang bentuknya 
cekung seperti mangkok dan berfungsi sebagai alat penempel pada host definitif.

Ikan yang terkena Trichodina sp. sering kali terjadi timbul gatal - gatal pada ikan sehingga ikan akan menggosok-gosokkan badan ke dasar kolam atau pinggir kolam, sehingga dapat menyebabkan luka di bagian tubuh ikan. Ikan yang terserang ektoparasit Trichodina sp. akan menjadi sangat lemah dengan warna tubuh yang sangat kusam dan pucat, Produksi lendir yang sangat berlebihan dan nafsu makan ikan ini sangat turun sehingga ikan menjadi kurus dan tidak bertenanga (Rahmi, 2012).

\section{MATERI DAN METODE}

\section{Pengambilan Sampel}

Metode penelitian ini menggunakan metode survey dengan pengambilan sampel sebanyak $5 \%$ dari populasi di kolam pembudidayaan ikan lele dumbo (Clarias gariepinus), dari empat lokasi pembudidayaan ikan lele dumbo (Clarias gariepinus) yang berbeda-beda, secara pengambilan dan besarnya sampel ditentukan dengan sengaja atau metode purposive sampling.

Metode ini pengambil sampel yang dilakukan secara acak (random sampling) terhadap ikan lele dumbo (Clarias gariepinus) dari kolam pembudidayaan yang di ambil di empat lokasi yang sudah ditentukan, lokasi tersebut berbeda Kecamatan ada empat Kecamatan yang ditinjau menurut populasi petani permbudidayaan kolam ikan lele dumbo (Clarias gariepinus) terbanyak yang ada di Kabupaten Sumenep, Jawa timur.

Kecamatan pertama yaitu kolam pembudidayaan A ikan lele dumbo (Clarias gariepinus) berada di Kecamatan Gulukguluk yang bersumber air dari sumur bor, kolam pembudidayaan B berada di Kecamatan Ganding bersumber air dari sumur bor, kolam pembudidayaan $\mathrm{C}$ berada di Kecamatan Pragaan bersumber air dari PDAM dan kolam pembudidayaan yang terakhir yaitu kolam pembudidayaan D di Kecamatan Pragan sumber airnya diambil dari air PDAM.

Sampel yang diambil adalah sampel ikan lele dumbo (Clarias gariepinus) yang siap dikonsumsi atau usia panen yang berumur satu bulan dan panjang lele dumbo (Clarias gariepinus) sekitar $\pm 18 \mathrm{~cm}$ diambil di Kabupaten Sumenep, Jawa Timur. Dari empat kolam pembudidayaan ikan lele dumbo (Clarias gariepinus) yang sudah dipilih untuk di ambil sampelnya, dan dua kolam pembudidayaan A dan B ikan lele dumbo (Clarias gariepinus) bersumber air dari sumur bor sebagian lagi di dua kolam pembudidayaan $\mathrm{C}$ dan $\mathrm{D}$ ikan lele dumbo (Clarias gariepinus) bersumber dari air PDAM.

Sampel hidup ikan lele dumbo (Clarias gariepinus) yang diambil dari empat tempat pembudidayaan yang berbeda lokasi dan masing-masing sebanyak 50 ekor per kolam pembudidayan ikan lele dumbo (Clarias gariepinus), pada kolam pembudidayaan A luas kolam 1,5 m x 2,5 m memilikikepadatan populasi \pm 1.000 ekor lele dumbo (Clarias gariepinus), Pada pembudidayaan kolam B kepadatan populasi yaitu sebanyak \pm 1.000 ekor dengan luas kolam $2 \mathrm{~m}$ x 2,5 m, pembudidayaan kolam $\mathrm{C}$ kepadatan populasi \pm 1.000 ekor dengan luas kolam $2 \mathrm{~m}$ x 2,5 m, dan pembudidayaan kolam $\mathrm{D}$ kepadatan populasi \pm 1.000 ekor dengan luas kolam $2 \mathrm{~m}$ $\mathrm{x} 2,5 \mathrm{~m}$, sehingga total sampel yang diambil sebanyak ikan lele dumbo (Clarias gariepinus) perkolamnya 50 sampel ikan lele dumbo (Clarias gariepinus) dan total sampel ikan lele dumbo (Clarias gariepinus) 200 sampel dari empat kolam yang berbeda-beda lokasinya.

Sampel hidup lele dumbo (Clarias gariepinus) diambil menggunakan jaring ikan, kemudian dimasukan dalam kantong plastik tertutup yang berisi air kolam dan diberi oksigen (Abo-Esa, 2008 dalam Ayu.L, 2011 ). Sampel ikan lele dumbo (Clarias gariepinus) kemudian dibawa ke Laboratorium Parasotologi Fakultas Kedokteran Hewan Universitas Wijaya Kusuma Surabaya, lalu ikan dipindahkan dalam ember dan dilakukan scrapping pada insang dan kulit yang mungkin terinfestasi adanya Trichodina sp. yang ada pada ikan lele dumbo (Clarias gariepinus) yang di periksa secara mikroskopi 


\section{Pemeriksaan Dengan Metode Scrapping}

Kulit ikan lele dumbo (Clarias gariepinus) diambil dengan melakukan scrapping dibagian tubuhnya, setelah itu hasil scrapping tersebut dengan segera di pindahkan ke object glass, dan menambahkan dua tetesan $\mathrm{NaCl}$ fisilogis lalu ditutup dengan cover glass. Pemeriksaan scrapping pada insang bisa juga dilakukan dengan membuka operculum ikan lele dumbo (Clarias gariepinus) kemudian melakukan scrapping pada bagian insang segera lalu dipindahkan ke object glass dan menambahkan dua tetesan $\mathrm{NaCl}$ fisiologis lalu menutupnya dengan cover glass, pemeriksaan hasil scrapping insang dan kulit diamati di bawah mikroskop dengan pembesaran 100x dan 400x (Noga, 2010).

Untuk memastikan jenis parasit apa yang ada di insang maupun di kulit ikan lele dumbo (Clarias gariepinus). Pemeriksaan dikatakan positif jika di bawah mikroskop terlihat adanya Trichodina sp. pada kulit atau insang ikan lele dumbo (Clarias gariepinus). Identifikasi Trichodina sp.yang di temukan menggunakan buku panduan yang ditulis oleh Anshary (2016), Afrianto dkk. (2015) dan Kurniawan (2012).

\section{Pemeriksaan Air Kolam}

Air kolam diukur suhu air dan derajat keasaman air $(\mathrm{pH})$. Pengukuran suhu air kolam dengan menggunakan termometer air ke dalam kolam selama 2 menit dengan kedalam $6 \mathrm{~cm}$ dari batas air, kemudian dilihat hasil pemeriksaan suhu kolam. Pengukuran derajat keasaman $(\mathrm{pH})$ dilakukan menggunakan kertas $\mathrm{pH}$ pada air kolam selama 2 menit dengan kedalam yang sudah ada ukuranya dikertas $\mathrm{pH}$, kemudian kertas derajat keasaman diangkat dan hasilnya di lihat dengan mencocokan pada kertas derajat keasaman $(\mathrm{pH})$ indikator.

\section{Analisis Data}

Penelitihan melakukan dengan model survei lapangan, model mengambil sampel hidup ikan lele dumbo (Clarias gariepinus) berdasar populasi pada saat penelitihan pada tempat pembudidayaan ikan lele dumbo (Clarias gariepinus) yang ditempatkan dalam populasi yang banyak dalam satu kolam. Hasil prevelensi laporan penelitihan tentang prevelensi ektoparasit protozoa Trichodina $s p$.

Dianalisis dengan uji chi square menggunakan program SPPS dan penelitihan ini untuk membandingkan tingkat infestasi Trichodina $s p$. dilihat dari populasi dan perbedaan air kolamnya (Statistical Program for Social Scientifie).

\section{HASIL}

Penelitian ini dilakukan dengan metode scrapping pada permukaan tubuh dan mengambil lamela insang dari 200 sampel ikan lele dumbo (Clarias gariepinus) yang dimana sebanyak 50 sampel dari kolam pembudidayaan A, 50 sampel dari pembudidayaan $\mathrm{B}, \quad 50$ sampel dari pembudidayaan $\mathrm{C}$, dan 50 sampel dari kolam pembudidayaan D prevelensi Trichodiniasis pada ikan lele dumbo di empat kolam pembudidayaan Kabupatan Sumenep, Jawa Timur dapat dilihat pada tabel 1 di bawah ini

Tabel 1. Prevalensi Trichodiniasis pada ikan ikan lele dumbo di empat kolam pembudidayaan Kabupaten Sumenep, Jawa Timur.

\begin{tabular}{|c|c|c|}
\hline \multirow{2}{*}{$\begin{array}{l}\text { PEMBUDIDAYAA } \\
\mathbf{N}\end{array}$} & \multicolumn{2}{|c|}{ TERINFEKSI } \\
\hline & $\begin{array}{l}\text { POSITI } \\
\mathrm{F}\end{array}$ & $\begin{array}{l}\text { NEGATI } \\
\mathrm{F}\end{array}$ \\
\hline A (50 Sampel) & $\begin{array}{c}14 \\
(28 \%)\end{array}$ & $36(72 \%)$ \\
\hline B (50 Sampe) & $\begin{array}{c}20 \\
(30 \%)\end{array}$ & $30(70 \%)$ \\
\hline C (50 Sampel) & $\begin{array}{c}32 \\
(64 \%)\end{array}$ & $18(36 \%)$ \\
\hline D (50 Sampel) & $\begin{array}{c}24 \\
(48 \%)\end{array}$ & $26(52 \%)$ \\
\hline
\end{tabular}

Pada tabel 1 terlihat bahwa prevalensi Trichodiniasis pada ikan lele dumbo di pembudidayaan A terdapat 14 sampel positif Trichodiniasis $(28 \%)$, pada pembudidayaan B terdapat 20 sampel positif Trichodiniasis (30\%), pembudidayaan C terdapat 32 sampel positif Trichodinasis (64\%), dan pembudidayaan D terdapat 24 sampel positif terinfeksi Trichodiniasis (48\%). Hasil 
perhitungan tersebut dirangkum dalam grafik dapat dilihat pada gambar 1 .

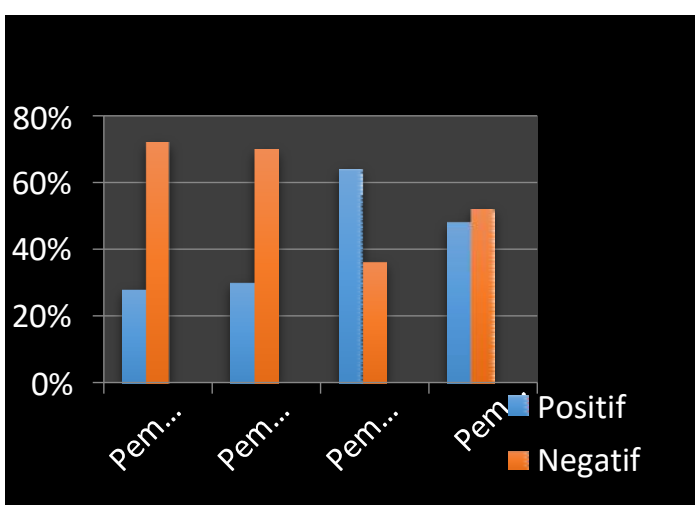

Gambar 1. Grafik prevalensi Trichodiniasis pada ikan lele dumbo di empat kolam pembudidayaan Kabupatan Sumenep, Jawa Timur.

Grafik prevalensi Trichodiniasis pada ikan lele dumbo di empat kolam pembudidayaan Kabupaten Sumenep, Jawa Timur (Gambar 1) menunjukkan bahwa tingkat infeksi Trichodiniasis yang paling tinggi terjadi di pembudidayaan $\mathrm{C}$ yaitu sebesar $64 \%$. Untuk mengetahui derajat infeksi Trichodiniasis pada ikan lele dumbo di empat kolam pembudidayaan Kabupaten Sumenep, Jawa Timur dapat dilihat pada tabel 2.

Pada tabel 2 terlihat bahwa hasil dari perhitungan derajat infeksi Trichodiniasis pada ikan lele dumbo di pembudidayaan A (1.86 individu parasit/ikan), pembudidayaan B (2.46 individu parasit/ikan), pembudidayaan C (5.62 individu parasit/ikan) dan pembudidayaan D (3.02). Berdasarkan pada penelitian Muntalim (2009) bahwa derajat infeksi 4.5-8.8 individu parasit/ikanmasuk dalam kategori ringan dan $>8,8$ individu parasit/ikanmasuk dalam kategori berat.

Sehingga dapat diketahui Trichodiniasis pada pembudidayaan A dengan jumlah Trichodina sp. sebanyak $93 \quad$ (1.86 individuparasit/ikan), pembudidayaan B dengan jumlah Trichodina sp. sebanyak 121 (2.46 individu parasit/ikan), pembudidayaan C dengan jumlah Trichodina sp. sebanyak 175 (5.62 individu parasit/ikan), dan pembudidayaan D dengan jumlah Trichodina sp. sebanyak 146 (3.02 individu parasit/ikan) termasuk ke dalam kategori derajat infeksi ringan.

Tabel 2. Hasil data derajat infeksi Trichodiniasis pada ikan lele dumbo di empat kolam pembudidayaan Kabupaten Sumenep, Jawa Timur.

\begin{tabular}{|c|c|c|c|}
\hline $\begin{array}{l}\text { Pembu } \\
\text { didayaan }\end{array}$ & $\begin{array}{c}\text { Total } \\
\text { Tricho } \\
\text { dina } \\
\text { sp. }\end{array}$ & $\begin{array}{c}\text { Ikan lele } \\
\text { dumbo } \\
\text { yang } \\
\text { terinfeksi }\end{array}$ & $\begin{array}{c}\text { Rata- } \\
\text { rata } \\
\text { Hasil }\end{array}$ \\
\hline $\mathbf{A}$ & 93 & 14 & $\begin{array}{c}1.86 \\
\text { individup } \\
\text { arasit/ika } \\
\mathrm{n}\end{array}$ \\
\hline B & 121 & 20 & $\begin{array}{c}2.46 \\
\text { individup } \\
\text { arasit/ika } \\
\mathrm{n}\end{array}$ \\
\hline C & 175 & 32 & $\begin{array}{c}5.62 \\
\text { individup } \\
\text { arasit/ika } \\
\mathrm{n}\end{array}$ \\
\hline D & 146 & 24 & $\begin{array}{c}3.02 \\
\text { individup } \\
\text { arasit/ika } \\
\mathrm{n}\end{array}$ \\
\hline
\end{tabular}

Hasil perhitungan tersebut dirangkum dalam grafik dapat dilihat pada gambar 2 .

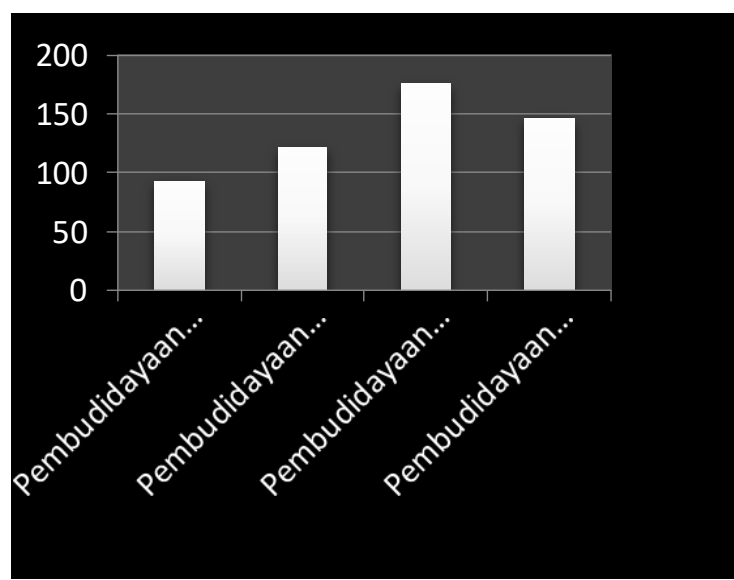

Gambar 2. Grafik derajat infeksi Trichodiniasis pada ikan lele dumbo di empat kolam pembudidayaan Kabupaten Sumenep, Jawa Timur.

Data tersebut kemudian digunakan untuk uji perbandingan yaitu menggunakan analisa data T-test dalam aplikasi software SPSS. 
Tabel 3. Rata-rata infeksi Trichodiniasis pada kolam pembudidayaan $\mathrm{A}$, pembudidayaan $\mathrm{B}$, pembudidayaan $\mathrm{C}$, dan pembudidayaan $\mathrm{D}$.

\begin{tabular}{cc}
\hline Kolam & Rata-rata \pm SD \\
\hline Pembudidayaan A & $1.86 \pm 3.356^{\mathrm{a}}$ \\
Pembudidayaan B & $2.46 \pm 3.903^{\mathrm{a}}$ \\
\hline Pembudidayaan C & $5.62 \pm 6.648^{\mathrm{d}}$ \\
\hline Pembudidayaan D & $3.02 \pm 4.732^{\mathrm{a}}$ \\
\hline
\end{tabular}

Keterangan: sumber data primer yang diolah T-test dalam SPSS

Superskrip yang berbeda pada kolom yang sama menunjukkan perbedaan yang sangat nyata $(\mathrm{P}<0,05)$.

Tabel 3 menunjukkan hasil data infeksi Trichodiniasis pada ikan lele dumbo di empat kolam pembudidayaan A, pembudidayaan B, pembudidayaan $\mathrm{C}$, dan pembudidayan $\mathrm{D}$ dengan total jumlah data masing-masing 50. Pada nilai rata-rata dapat dilihat bahwa Trichodiniasis yang paling banyak menginfeksi ikan lele dumbo di kolam pembudidayaan C 5.62 sedangkan kolam pembudidayaan A 1.86, kolam pembudidayaan B 2.46, dan kolam pembudidayaan D 3.02 maka selisih antara kolam pembudidayaan keempatnya menunjukkan perbedaan yang signifikan.

Pada Levene's Test for Equality of Variances menunjukkan nilai $\mathrm{F}=5.891$ dan Sig. 0,001 $(\mathrm{P}=0,001)$ yang artinya $\mathrm{P}$ dibawah 0,05 maka data tersebut tidak homogen atau terdapat perbedaan yang sangat nyata (Equal variances not assumed).

Hasil dari penelitian ini diketahui parasit protozoa Trichodina $s p$. yang menginfeksi ikan lele dumbo di empat kolam pembudidayaan Kabupaten Sumenep, Jawa Timur dapat dilihat pada gambar 3 .

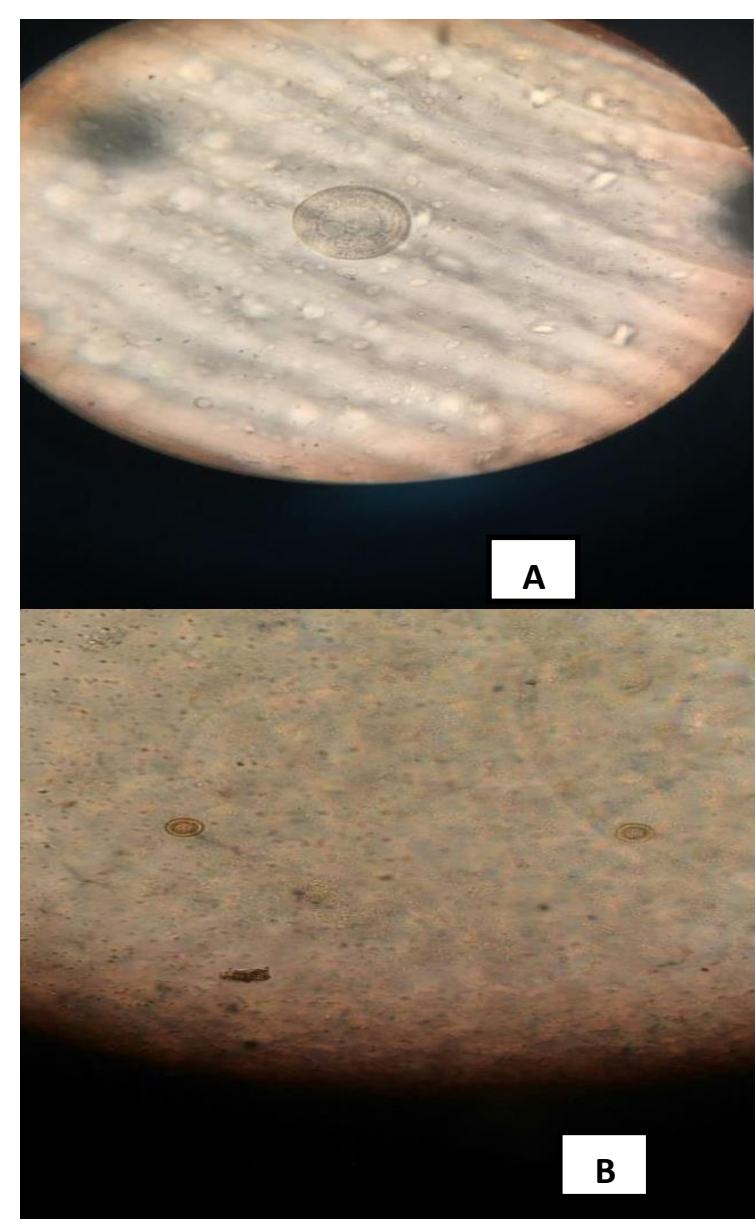

Gambar 3. Trichodina sp. pada ikan lele dumbo A Trichodina sp. (400x)

B Trichodina sp. (100x).

Populasi suatu parasit pada ikan dapat dimonitor melalui identifikasi parasit yaitu dengan cara menghitung prevalensi dan derajat infeksinya (Mas'ud, 2011). Prevalensi adalah presentasi ikan yang terserang penyakit dibagi dengan jumlah sampel ikan yang diamati. Prevalensi hanya untuk mengetahui presentase jumlah ikan yang terserang penyakit disetiap lokasi.

Sedangkan untuk mengetahui besarnya serangan parasit pada ikan per individu dilakukan dengan cara menghitung derajat infeksi, sehingga dapat diketahui berapa besar tingkat serangan parasit pada setiap ikan.

Berdasarkan penelitian dari 200 sampel ikan lele dumbo yang telah diperiksa menunjukkan hasil adanya infeksi 
Trichodina sp. yang menyebabkan Trichodiniasis atau penyakit gatal pada ikan lele dumbo. Infeksi Trichodiniasis pada kolam pembudidayaan $\mathrm{C}$ sangat berbeda nyata $\quad(\mathrm{P}<0.05)$ dari pada kolam pembudidayaan $\mathrm{A}$, pembudidayaan $\mathrm{B}$, dan pembudidayaan $\mathrm{D}$.

Prevalensi Trichodiniasis tertinggi terdapat dikolam pembudidayaan C $(64 \%)$ dengan derajat 5.62 infeksi individu parasit/ikan termasuk kategori infeksi berat sedangkan prevalensi Trichodiniasis di kolam pembudidayaan A $(28 \%)$ dengan derajat infeksi 1.86 individu parasit/ikan, kolam pembudidayaan B (30\%) dengan derajat infeksi 2.46 individu parasit/ikan, dan kolam pembudidayaan D (48\%) dengan derajat infeksi 3.02 individu parasit/ikan termasuk kategori infeksi ringan.

Trichodina sp. dengan intensitas yang tinggi disebabkan oleh ketidak seimbangan hubungan antara inang, parasit, lingkungan, berupa kurangnya nutrisi serta kualitas air dan $\mathrm{pH}$ yang tidak sesuai (Windarto dkk., 2013).

Pada hasil survey di lapangan, yaitu di kolam pembudidayaan A, kolam pembudidayaan $\mathrm{B}$, kolam pembudidayaan $\mathrm{C}$, dan kolam pembudidayaan kolam D memiliki besaran luas kolam, populasi, dan umur ikan lele dumbo yang hampir sama.

Kolam pembudidayaan A yang berada di Kecamatan Guluk - guluk dengan luas kolam $1,5 \mathrm{~m} \times 2,5 \mathrm{~m}$ memiliki kepadatan populasi \pm 1000 ekor (umur 1 bulan), pembudidayaan $B$ yang berada di Kecamatan Ganding dengan luas kolam $2 \mathrm{~m}$ x 2,5 m memiliki kepadatan populasi \pm 1000 ekor (umur 1 bulan), pembudidayaan $\mathrm{C}$ yang berada di Kecamatan Pragaan dengan luas kolam $2 \mathrm{~m} \times 2,5 \mathrm{~m}$ memiliki kepadatan populasi \pm 1000 ekor (umur 1 bulan) dan pembudidayaan D yang berada di Kecamatan Pragaan dengan luas kolam $2 \mathrm{~m}$ x 2,5 m memiliki kepadatan populasi \pm 1000 ekor (umur 1 bulan).

Berdasarkan Badan Standarisasi Nasional (2014), dengan SNI 6484.3:2014 waktu umur pemeliharaan 2-2,5 bulan jumlah kepadatan penebaran ikan lele dumbo pada kolam yaitu $100-150 \mathrm{ekor} / \mathrm{m}^{3}$. Oleh karena itu, maka padat tebar ikan lele dumbo pada kolam pembudidayaan $\mathrm{A}, \mathrm{B}, \mathrm{C}$, dan D telah sesuai dengan SNI 6484.3:2014.
Sumber air pada kolam pembudidayaan A, dan kolam pembudidayaan B memiliki sumber air yang sama yaitu dari air sumur dan menggunakan mesin pompa, sedangkan kolam pembudidayaan $\mathrm{C}$, dan kolam pembudidayaan $\mathrm{D}$ juga memiliki sumber air yang sama yaitu dari PDAM, tetapi air kolam di pembudidayaan A berwarna bening kecokelatan, kolam di pembudidayaan B berwarna bening kecoklatan, dan air kolam di pembudidayaan $\mathrm{C}$ berwarna hijau lumut dan kolam di pembudidayaan D berwarna hijau bening hal ini disebabkan karena faktor pemeliharaan kolam yang dimana pada kolam pembudidayaan A dan B frekuensi pergantian air sering dilakukan setiap minggu sekali dan beratap sedangkan pada kolam pembudidayaan C dan D satu bulan sekali dan tidak beratap.

Menurut Gunawan (2016), kelebihan sinar matahari akan menyebabkan pertumbuhan lumut tidak terkendali, oksigen dan kualitas air menurun, air cepat kotor. Hal ini menyebabkan ikan stres, selera makan menurun, dan stamina ikan menjadi lemah sehingga mudah terserang penyakit. Jika ikan mengalami stres atau kualitas air yang menurun maka parasit Trichodina sp. ini akan berkembang dengan cepat (Pramono dan Hamdan, 2008).

Suhu air kolam pembudidayaan A $26^{\circ} \mathrm{C}$, kolam pembudidayaan $\mathrm{B} 27^{\circ} \mathrm{C}$ dan kolam pembudidayaan $\mathrm{C} 28^{\circ} \mathrm{C}$ sedangkan suhu air kolam pembudidayaan $\mathrm{D}$ lebih tinggi yaitu $27^{\circ} \mathrm{C}$. Fisheries and Aquaculture of FAO (1985) menyatakan bahwa Trichodina $s p$. bereproduksi dengan cara pembelahan biner (membelah menjadi dua) dan konjugasi dengan temperatur optimum untuk reproduksi $20-29^{\circ} \mathrm{C}$. Menurut Baticados (1992), besarnya nilai derajat infeksi Trichodina sp. disebabkan oleh kecepatan pembelahan pada Trichodina $s p$. setiap $1 / 2$ jam.

Adapun penularan Trichodina $s p$. melalui air atau kontak langsung dengan ikan yang terinfeksi dan penularannya akan semakin cepat jika kualitas air rendah pada tempat ikan yang dipelihara, terutama pada kolam pembudidayaan $\mathrm{C}$ dimana lebih banyak ditemukannya Trichodina $s p$. Organisme yang berkembang biak dengan 
pembelahan biner (membela menjadi dua) ini akan menghasilkan organisme baru yang akan kembali ke inang semula atau mencari inang baru di dalam air.

\section{KESIMPULAN}

Kesimpulan dari hasil penelitian Trichodiniasis pada sampel ikan lele dumbo (Clarias gariepinus) di empat kolam pembudidayaan Kabupaten Sumenep, Jawa Timur menunjukkan bahwa infeksi Trichodiniasis tertinggi berada di kolam.

Pembudidayaan $\mathrm{C}$ yang berada di Kecamatan Pragaan dengan prevalensi dan derajat infeksi termasuk kategori infeksi berat/tinggi dan pada kolam pembudidayaan A yang berada di Kecamatan Guluk - guluk, kolam pembudidayaan B yang berada di Kecamatan Ganding, dan kolam pembudidayaan D yang berada di Kecamatan Pragaan prevalensi dan derajat infeksi termasuk kategori infeksi ringan/rendah.

\section{REFERENSI}

Abo-Esa, J.F.K., 2008. Study Some Ectoparasit Disease of Catfish (Clarias gariepinus) with Their Control by Ginger; Zingiber officinale. Mediteranian Aquaculture Journal: 1-9.

Afifah, B., A. Nasrudin dan M. Gofron, 2014. Efektifitas Perendaman Benih Ikan Mas (Cyprinus carpio L.) Dalam Larutan Perasan Daun Api-Api (Avicennia Marina) Terhadap Penurunan Jumlah Trichodina sp.Jurnal Sains dan Seni Pomits: Vol.3 (2).

Afrianto, E. Lisa, J. Juna dan Hendi, 2015. Penyakit Ikan. Jakarta. Penebar Swadaya.

Anshary, H. 2009. Modul Pembelajaran Berbasis Student Center Learning (SLC) Mata Kuliah Parasitologi. Lembaga Kajian dan Pengembangan Pendidikan (LKKP). Universitas Hasanuddin. Makassar.

Anshary, H. 2016. Parasitologi Ikan: Biologi, Identifikasi dan Pengendaliannya. Yogyakarta : Deepublish. hal.1, 46-61.

Ayu, L. 2011, Skripsi Tentang Prevelensi Ektoparasit Protozoa Trichodina sp.
Pada Ikan Lele Dumbo(Clarias gariepinus) di Kabupaten Gresik ,Gresik.

Badan Standarisasi Nasional. 2014. SNI 6484.3:2014 Ikan Lele Dumbo (Clarias sp.) Bagian 3: Produksi Induk. Jakarta: Badan Standarisasi Nasional.

Cahyono, B, 2009. Budidaya Lele Dan Betutu (Ikan Langkah Bernilai). Pustaka Mina. Jakarta.

Farikhah dan B. Badrun. 2013. Panduan Lengkap Budidaya Lele. Yogyakarta : Familia.

Gunawan. S, 2016. 99\% Sukses Budidaya Lele. Jakarta : Penebar Swadaya.

Kurniawan, A., 2012. Penyakit Akuatik Pangkal Pinang, Kalimatan Tengah : UBB Press.

Mahasri, G. dan Kismiyati, 2011. Buku Ajar Parasit dan Penyakit Ikan I (Ilmu Penyakit Protozoa pada Ikan dan Udang). Surabaya : FPK Universitas Airlangga.

Mas'ud, F. 2011. Prevalensi dan Derajat Infeksi Dactylogyrus sp. pada Insang Benih Bandeng (Chanos chanos) di Tambak Tradisional, Kecamatan Glagah, Kabupaten Lamongan. Jurnal Ilmiah Perikanan dan Kelautan: Vol. 3 No. 1.hal. 8-15.

Pramono, T.B. dan H. Syarif, 2009. Infeksi Parasit pada Permukaan Tubuh Ikan Nilem (Osteochitus hasellti) yang Diperdagangkan di PPI Purbalingga. Berkala Ilmiah Perikanan: 79-82.

Purwono, J., S. Sihiningsi, dan W.A. Endrik, 2011. Strategi Pengembangan Usaha Pembesaran Ikan Lele Sangkuriang (Clarias gariepinus strain sangkuriang) di Kecamatan Ciampea Kabupaten Bogor. Fakultas Ekonomi dan Manajemen. Institut Pertanian Bogor, Bogor.

Rahmi, 2012. Identifikasi Ektoparasit Pada Ikan Nila (Oreochromis niloticus) yang Dibudidayakan Pada Tambak Kabupaten Maros Jurusan Budidaya Perairan Fakultas Pertanian Universitas Muhammadiyah Makassar, Makassar. 
e-ISSN 2685-8894; pISSN 2460-9773

Jurnal Vitek Bidang Kedokteran Hewan Vol.9, November 2019

Setiadi, R., 2009. Efektivitas Perendaman 24 Jam Benih Ikan Lele Dumbo Clarias sp. Dalam Larutan Paci-Paci (Leucas Lavan Dulanefolia) Terhadap Perkembangan Populasi Trichodina sp. Fakultas Perikanan dan Kelautan. Institut Pertanian Bogor.

Zaki, 2009. Budi Daya Ikan Lele (Clarias batrachus) '.http://wilystra2008.biologi.c om/journal/item/54/Budi_Daya

_Ika n_Lele(Clariasbatrachus) 